\title{
Исследование параметров наноразмерного слоя в наногетероструктурах на основе полупроводниковых соединений $A^{\mathrm{ll}} \mathrm{B}^{\mathrm{Vl} 1}$
}

(С) М.Б. Караваев, Д.А. Кириленко, Е.В. Иванова, Т.Б. Попова, А.А. Ситникова,

И.В. Седова, М.В. Заморянская

Физико-технический институт им. А.Ф. Иоффе Российской академии наук,

194021 Санкт-Петербург, Россия

E-mail: estonianchameleon@gmail.com

(Получена 28 мая 2016 г. Принята к печати 24 июня 2016 г.)

Методами локальной катодолюминесценции и рентгеноспектрального микроанализа проведено комплексное исследование широкозонных наногетероструктур на основе $\mathrm{ZnSe}$, полученных методом молекулярнопучковой эпитаксии. Было показано, что используемые методы позволяют неразрушающим способом определять глубину залегания, элементный состав и геометрические параметры наноразмерного слоя ZnCdSe. Точность результатов контролировалась методом просвечивающей электронной микроскопии. Методики исследования основаны на возможности варьирования энергии первичного электронного пучка, что приводит к изменению областей генерации характеристического рентгеновского излучения и катодолюминесценции.

DOI: $10.21883 / \mathrm{ftp} .2016 .12 .44082 .8249$

\footnotetext{
${ }^{1}$ Полный текст этой статьи будет опубликован в журнале „Физика и техника полупроводников“, том 51 вып. 1.
} 